\title{
Clinical value of leukocyte counts in evaluation of patients with suspected appendicitis in emergency department
}

\author{
Acil serviste apandisitten kuşkulanılan hastaların değerlendirilmesinde \\ lökosit sayımlarının klinik değeri \\ Mohammad Zikrullah TAMANNA, ${ }^{1}$ Uzma ERAM, ${ }^{2}$ Turki Mohsen AL HARBI, ${ }^{1}$ \\ Saleh Awad ALRASHDI, ${ }^{1}$ Shafkat Ullah KHATEEB, ${ }^{1}$ \\ Saleem Ahmed ALADHRAI, ${ }^{1}$ Abdul Muthalib HUSSAIN ${ }^{3}$
}

\section{BACKGROUND}

The objective of this study was to assess the value of total leukocyte count in patients presenting to the emergency department with sign and symptoms suggestive of acute appendicitis.

\section{METHODS}

Patient demographics, presenting sign, and symptoms, initials total leukocyte count and discharge diagnosis was documented retrospectively. Admitted patients were followed for surgical and clinical outcomes, and discharged patients followed up by telephonic interview.

\section{RESULTS}

Out of 116 eligible patients 48 patients was found to have acute appendicitis. Total leukocyte count $\geq 10.000 \mathrm{cell} / \mathrm{mm}^{3}$ yielded a sensitivity of $89.58 \%$ and a specificity of $64.71 \%$. The positive predictive value (PPV) was $64.18 \%$, and the negative predictive value (NPV) was $89.80 \%$. The positive likelihood ratio (+LR) was 2.54, and the negative likelihood ration (-LR ) was 0.16 . The area under the curve for the receiver operating characteristic (ROC) curve was 0.822 , which was moderately accurate.

\section{CONCLUSION}

The total leukocyte counts are helpful in the diagnosis and exclusion of acute appendicitis. The elevated leukocyte count $\geq 10,000$ cells $/ \mathrm{mm}^{3}$ was statistically associated with the presence of acute appendicitis. The ROC curve suggests there is value of total leukocyte counts and has sufficient sensitivity and specificity to be clinical value in the diagnosis of acute appendicitis.

Key Words: Abdominal pain; appendicitis; leukocyte counts.

\section{$A M A C$}

$\mathrm{Bu}$ çalışmanın amacı acil servise akut apandisiti düşündüren belirti ve bulgularla gelen hastalarda toplam lökosit sayımının değerini belirlemekti.

\section{GEREÇ VE YÖNTEM}

Hastanın demografik özellikleri, görülen belirtiler ve bulguları, toplam lökosit sayıları ve hastaneden çıkıştaki tanıları geriye dönük olarak belgelendi. Kabul edilen hastalar cerrahi ve klinik sonuçlar açısından izlendi, çıkışı yapılan hastalar telefon görüşmeleriyle takip edildi.

\section{BULGULAR}

Yüz on altı hastanın $48^{\prime}$ inde akut apandisit saptantı. Toplam $\geq 10,000 / \mathrm{mm}^{3}$ şeklindeki lökosit sayıs $\% 89,58$ duyarl1lık ve \%64,71 özgüllüğe sahipti. Pozitif (PPV) ve negatif (NPV) öngörü değerleri sırasıyla \%64,18 ve \%89,80 idi. Pozitif (+LR) ve negatif (-LR) olasılık oranları ise sırasıyla 2,54 ve 0,16 şeklindeydi. Algılayıcı işletim eğrisinin (ROC-receiver operating characteristics) altında kalan alanı 0,822 olup orta derecede doğruluk derecesini sergilemekteydi.

\section{SONUÇ}

Akut apandisit tanısı koyma veya bu tanının dışlanmasında toplam lökosit sayıları yardımcı olur. Yüksek lökosit sayısı $\left(\geq 10.000 / \mathrm{mm}^{3}\right)$ istatistiksel açıdan akut apandisit varlığıyla ilişkiliydi. ROC eğrisi akut apandisit tanısında toplam lökosit sayılarının klinik değer taşıyacak şekilde yeterli duyarlılık ve özgüllüğe sahip olduğunu düşündürmektedir.

Anahtar Sözcükler: Karın ağrısı; apandisit; lökosit sayıları.

\footnotetext{
${ }^{1}$ Department of Emergency Medicine, King Fahad Medical City, Riyadh, Saudia Arabia; ${ }^{2}$ Department of Community Medicine, J.N Medical Collage, AMU Aligarh, India; ${ }^{3}$ Department of Pulmonary and Critical Care Medicine, King Fahad Medical City, Riyadh, Saudia Arabia.
}

${ }^{1}$ Kral Fahd Tıp Kenti, Acil Tıp Bölümü, Riyad, Suudi Arabistan; ${ }^{2}$ JN Tıp Koleji, Toplum Hekimliği Bölümü, AMU Aligarh, Hindistan; ${ }^{3}$ Kral Fahd Tıp Kenti, Göğüs Hastalıkları ve Yoğun Bakım Kliniği, Riyad, Suudi Arabistan. 
Acute appendicitis is a common consideration in the differential diagnosis of patients with right lower abdominal pain presenting to the emergency department (ED). Both routine history and physical examination remain the most effective and practical diagnostic modalities. To increase diagnostic accuracy, inflammatory variables such as leukocyte count, Creactive protein (CRP), and body temperature have been studied. ${ }^{[1,2,]}$ None of these is specific for acute appendicitis, and their ability to improve on the preoperative diagnosis is doubtful. The prevailing perception is that the patients with appendicitis will have a high leukocyte count. Most of the ED physicians, while evaluating acute appendicitis, obtain a complete blood cell count (CBC), with the expectation that a high leukocyte count will support the diagnosis. Considering the overlap with other inflammatory processes mimicking acute appendicitis, the diagnostic value of the leukocyte count remains controversial. Several literatures recommend total leukocyte count as part of the evaluation with suspected appendicitis. ${ }^{[3]}$ However, some studies do not recommend total leukocyte count because of the limitation of this test. ${ }^{[4]}$ Most of the studies have calculated the sensitivity and specificity at arbitrarily chosen threshold values for acute leukocyte count. Only a few have used receiver operating characteristic (ROC) curve analysis in patients with suspected acute appendicitis, but either without calculating the area under the ROC curve (AUC) or without defining the cut-off values with highest sensitivity and specificity. ${ }^{[5,6]}$ However, in this continuous variable, ROC curve analysis is a statistically more appropriate approach.

In this study, we tried to evaluate retrospectively the diagnostic value of total leukocyte count by performing ROC curve analysis in consecutive patients presenting to an ED with signs and symptoms suggestive of acute appendicitis.

\section{MATERIALS AND METHODS}

This retrospective study was conducted in a 1500bed tertiary care teaching hospital in Saudi Arabia. The institutional review board approval was obtained. The present investigation included patients who presented to the ED between June 2011 and January 2012 with right lower quadrant pain who were suspected as having acute appendicitis. A total of 159 patient charts that met the inclusion criteria were reviewed. The study was designed to assess the impact of Alvarado score and computed tomography (CT) scan in the diagnosis of acute appendicitis. This investigation represents a planned subanalysis of the total leukocyte count obtained as part of routine data collected from the enrolled patients.

Patient demographics and presenting signs and symptoms were documented from the pro forma. All laboratory tests were obtained at the discretion of the managing physicians. If appendectomy or surgical intervention was performed, all appendices and other specimens were submitted to the pathology department. Official radiology reports, the surgical pathology report, and medical records were reviewed retrospectively. Patients were excluded if lost to follow-up or transferred to another hospital. Other alternative diagnoses were recorded. If acute appendicitis was considered unlikely and no other acute etiology was found, patients were discharged with discharge instruction to return if symptoms worsened, with appropriate follow-up. All patients discharged from the ED were followed up by telephone interview after the index visit.

Recorded data included age, gender, total leukocyte counts from the $\mathrm{CBC}$ count obtained during the initial ED presentation, presence of appendicitis (operative and pathologic report), and final diagnosis. Total leukocyte counts or white blood cell count (WBC) $>10,000$ cells $/ \mathrm{mm}^{3}$ were a priori classified as abnormal. Total leukocyte counts of up to 10,000 cells $/ \mathrm{mm}^{3}$ were chosen empirically to maximize sensitivity.

\section{Data analysis}

Analysis of the data on total leukocyte counts included determination of sensitivities, specificities, positive predictive value (PPV), negative predictive value (NPV), positive likelihood ratio (+LR), and negative likelihood ratio (-LR). All results were reported with $95 \%$ confidence intervals $(95 \% \mathrm{CIs})$. ROC curves were plotted for these variables along with calculation of the AUC with $95 \%$ CI. We calculated the AUC for leukocyte counts using the Hanley-McNeil method for paired data. ${ }^{[7]}$ The AUC is a summary statistic of diagnostic accuracy (based on all possible cutoff values). The AUC can have values between 0 and 1. The practical lower limit for the AUC of a diagnostic test is 0.5 . The test results are classified as uninformative (AUC $=0.5)$, less accurate $(0.5<\mathrm{AUC} \leq 0.7)$, moderately accurate $(0.7<\mathrm{AUC} \leq 0.9)$, highly accurate $(0.9<$ AUC $<1)$, and perfect $(\mathrm{AUC}=1) .{ }^{[8]}$ To calculate sensitivity and specificity, we used cut-off values for the leukocyte counts. The selected cut-off value provided an ideal balance between sensitivity and specificity for the diagnosis of acute appendicitis. Clinical and analytical variables of the acute appendicitis and normal appendix group were compared using chisquare test (Table 1). Statistical analyses were performed using MedCalc for Windows version 8.2.1.0.

\section{RESULTS}

The study began with retrieval of 159 patients who presented to the ED with right lower quadrant pain. Forty-three were excluded because they were transferred to another hospital after being diagnosed as ap- 
Table 1. Chi-square tests

\begin{tabular}{|c|c|c|c|c|c|}
\hline & Value & Df & $\begin{array}{c}\text { Asymp. Sig. } \\
\text { (2-sided) }\end{array}$ & $\begin{array}{c}\text { Exact Sig. } \\
\text { (2-sided) }\end{array}$ & $\begin{array}{c}\text { Exact Sig. } \\
\text { (2-sided) }\end{array}$ \\
\hline Pearson chi-square & $33.991^{\mathrm{a}}$ & 1 & .000 & & \\
\hline Continuity correction $^{\mathrm{b}}$ & 31.802 & 1 & .000 & & \\
\hline Likelihood ratio & 37.630 & 1 & .000 & & \\
\hline Fisher's exact test & & & & .000 & .000 \\
\hline $\mathrm{N}$ of valid cases & 116 & & & & \\
\hline
\end{tabular}

Table 2. Total leukocyte count and appendicitis

\begin{tabular}{|c|c|c|c|c|}
\hline \multirow{2}{*}{\multicolumn{2}{|c|}{$\begin{array}{l}\text { Count } \\
\text { Total WBC } \\
\text { count }\end{array}$}} & \multicolumn{2}{|c|}{ Diagnosis } & \multirow[b]{2}{*}{ Total } \\
\hline & & $\begin{array}{c}\text { Acute } \\
\text { appendicitis }\end{array}$ & $\begin{array}{c}\text { No } \\
\text { appendicitis }\end{array}$ & \\
\hline \multirow[t]{2}{*}{ WBC } & $\geq 10,000$ & 43 & 24 & 67 \\
\hline & $<10,000$ & 5 & 44 & 49 \\
\hline \multicolumn{2}{|l|}{ Total } & 48 & 68 & 116 \\
\hline
\end{tabular}

A $2 \times 2$ table for patients with and without appendicitis. For the purpose of this analysis, a WBC (leukocyte count) $\geq 10,000$ cells $/ \mathrm{mm}^{3}$ was considered abnormal.

pendicitis due to non-availability of beds in the surgical ward. Two were discharged against medical advice, and these two patients were lost to follow-up. One hundred and sixteen patients were included in the study.

Total leukocyte count was measured in 116 patients. Table 2 shows a standard $2 \times 2$ table for total leukocyte count in patients with and without appendicitis. Total leukocyte count $\geq 10,000$ cells $/ \mathrm{mm}^{3}$ yielded a sensitivity of $89.58 \%$ (95\% CI: $77.34 \%-96.53 \%$ ) and a specificity of $64.71 \%$ (95\% CI: $52.17 \%-75.92 \%)$. The PPV was $64.18 \%$ (95\%CI: $51.53 \%-75.3 \%)$ and the NPV was $89.80 \%(95 \% \mathrm{CI}=77.77 \%-96.60 \%)$. The + LR was 2.54 (95\% CI: 1.81-3.55) and the -LR was 0.16 (95\% CI: 0.07-0.38) (Table 3).

Table 4 shows the diagnosis of acute appendicitis for different ranges of total leukocyte counts, which was statistically significant $(\mathrm{p}<0.0001)$.

Table 5 shows an ROC curve for total leukocyte counts. The AUC for the ROC curve was 0.822 (95\% CI: 0.740-0.887), which was moderately accurate. If one chose to maximize both sensitivity and specificity, an optimum cut-off for an abnormal total leukocyte count would be 10,700 cells $/ \mathrm{mm}^{3}$, which yielded a sensitivity of $89.6 \%$ and a specificity of $73.5 \%$ (Fig. 1).

\section{DISCUSSION}

Inflammatory markers have long been used to improve the diagnostic performance in acute appendicitis. Measurement of total leukocyte count is usually considered a routine part of the work-up for acute appendicitis. Several studies suggest that an elevated total leukocyte count is usually the earliest laboratory finding of appendiceal inflammation. ${ }^{[1,2,6,9]}$ Neither leukocyte count nor neutrophil percentage is specific for acute appendicitis. Leukocytosis is a nonspecific reaction caused by acute or chronic inflammation, acute physical or emotional stress, and several other conditions. Most of the previous studies have tried to compare the relationship between total leukocyte count and acute appendicitis using sensitivity, specificity, PPV, and NPV using arbitrary cut-off points with the upper reference limit. ${ }^{[1,2,6,7,10,11]}$ The difficulty with this type of analysis is that PPV and NPV are directly dependent on the prevalence of the disease. As these variables are obtained from various study

Table 3. Sensitivities, specificities, positive predictive values (PPV), negative predictive values (NPV), positive likelihood ratios ( $+\mathrm{LR})$, and negative likelihood ratios (-LR) with $95 \%$ confidence intervals ( $95 \%$ CIs) at the cut-off value of total leukocyte count $\geq 10,000$ cells $/ \mathrm{mm}^{3}$

\begin{tabular}{lcc}
\hline Sensitivity & $89.58 \%$ & $77.34 \%-96.53 \%$ \\
Specificity & $64.71 \%$ & $52.17 \%-75.92 \%$ \\
Positive likelihood ratio & 2.54 & $1.81-3.55$ \\
Negative likelihood ratio & 0.16 & $0.07-0.38$ \\
Disease prevalence & $41.38 \%$ & $32.31 \%-50.90 \%$ \\
Positive predictive value & $64.18 \%$ & $51.53 \%-75.53 \%$ \\
Negative predictive value & $89.80 \%$ & $77.77 \%-96.60 \%$
\end{tabular}


Table 4. Acute appendicitis for different ranges of total leukocyte counts

\begin{tabular}{lccccc}
\hline Diagnosis & $<8$ & 8 to $<10$ & 10 to $<12$ & 12 to $<15$ & $\geq 15$ \\
\hline Appendicitis (48) & 1 & 4 & 8 & 14 & 21 \\
No appendicitis (68) & 23 & 21 & 9 & 9 & 6 \\
Total (116) & 24 & 25 & 17 & 23 & 27 \\
\hline
\end{tabular}

Chi-square 38.914; DF 4; Significance level p $<0.0001$; Contingency coefficient 0.501 .

populations with different prevalences of the disease, the results have to be interpreted carefully. Moreover, sensitivity and specificity alone do not allow clinicians to directly apply the result of diagnostic tests to individual patients. ROC analysis allows calculation of cut-off values with the highest sensitivity and specificity. ROC analysis, however, is independent of disease prevalence.

Only a few studies have done ROC analysis of inflammatory variables in acute appendicitis. ${ }^{[6,12]}$ However, in some, only the appearance of the ROC curve was used or the AUC was calculated without reporting the cut-off value with the highest sensitivity and specificity.

In our study, while doing ROC analysis, the AUC for the ROC curve was 0.822 (95\% CI: $0.740-0.887$ ), which was moderately accurate. If one chose to maximize both sensitivity and specificity, an optimum cut-off for an abnormal total leukocyte count would be 10,700 cells $/ \mathrm{mm}^{3}$, which yielded a sensitivity of $89.6 \%$ and a specificity of $73.5 \%$ (Fig. 1 ).

Other investigators have constructed ROC analysis with comparable results. Andersson et al. ${ }^{[13]}$ found an AUC of 0.80, Paajanen et al. ${ }^{[6]}$ found an AUC of 0.76, Rodriguez-Sanjuan et al. ${ }^{[14]}$ found an AUC of 0.67 , and Körner et al. ${ }^{[15]}$ found an AUC of 0.69 (95\% CI: $0.65-0.73)$.

Table 5. Receiver operating characteristic curve analysis of total leukocyte count and area under curve with $95 \%$ confidence interval

\begin{tabular}{ll}
\hline Variable & Count \\
Classification variable & Diagnosis \\
Sample size & 116 \\
Positive group: diagnosis $=1$ & 48 \\
Negative group: diagnosis $=0$ & 68 \\
Disease prevalence $(\%)$ & Unknown \\
Area under the ROC curve (AUC) & 0.822 \\
Standard Error & 0.0398 \\
95\% Confidence interval & b \\
z statistic $_{\text {Significance level P }(\text { Area }=0.5)}$ & 0.740 to 0.887 \\
\hline
\end{tabular}

aHanley \& McNeil, 1982; 'Binomial exact;

Criterion values and coordinates of the ROC curve;

Criterion corresponding with highest Youden index.
Our present study has several limitations due to inherent flaws of a retrospective study. Our study comprised a review of patients' medical records and pathological reports. The retrospective nature of the study may limit the diagnostic performance, and was limited to one institution. Another limitation was that we did not study the diagnostic value of neutrophils. We also did not study how total leukocyte counts might perform as part of a scoring system or combination of test results.

There is a statistically significant relationship between total leukocyte count and acute appendicitis in ED patients presenting with signs and symptoms suggestive of acute appendicitis. According to our study, the relationship is modest and clinically very useful. There is need to perform more investigations to provide further information for the diagnosis of acute appendicitis, such as imaging, short-term observation for clinical evaluation, and repeated physical and labora-

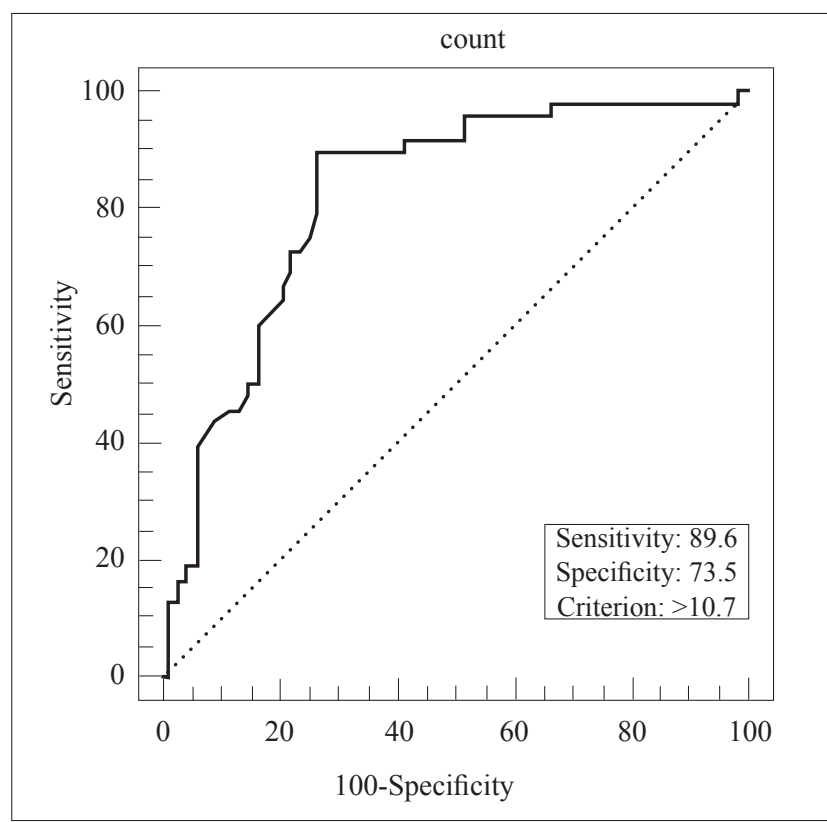

Fig. 1. ROC curve for total leukocyte counts. The AUC for the ROC curve was 0.822 (95\% CI: $0.740-0.887$ ), which was moderately accurate. If one chose to maximize both sensitivity and specificity, an optimum cut-off for an abnormal total leukocyte count would be 10,700 cells $/ \mathrm{mm}^{3}$, which yielded a sensitivity of $89.6 \%$ and a specificity of $73.5 \%$. 
tory examinations. Our findings indicate that the total leukocyte count offers a rapid and helpful method to predict and discriminate appendicitis in the ED.

In conclusion, although elevated leukocyte count is a nonspecific inflammatory marker, high leukocyte count is helpful in the diagnosis and exclusion of appendicitis. It is inexpensive, objective, and readily available without the risk of radiation, and useful for the emergency physician.

\section{Acknowledgements}

The author thanks Dr. Abdul Muthalib Hussain for inspiring and giving proper guidance in writing this article.

\section{REFERENCES}

1. Peltola H, Ahlqvist J, Rapola J, Räsänen J, Louhimo I, Saarinen M, et al. C-reactive protein compared with white blood cell count and erythrocyte sedimentation rate in the diagnosis of acute appendicitis in children. Acta Chir Scand 1986;152:55-8.

2. Elangovan S. Clinical and laboratory findings in acute appendicitis in the elderly. J Am Board Fam Pract 1996;9:75-8.

3. Kozar RA, Roslyn JJ. The appendix. In: Schwartz SI, Shires SG, Spencer FC, Daley JM, Fischer JE, GallowayAC, editors. Principles of surgery. 7th ed. New York, NY: McGraw Hill; 1999. p. 1383-95.

4. Hartman GE. Acute appendicitis. In: Behrman RE, Kliegman RM, Jenson HB, editors. Nelson Textbook of Pediatrics. Phildephia, PA: WB Saunders Company; 2000. p. 1179.

5. van Dieijen-Visser MP, Go PM, Brombacher PJ. The value of laboratory tests in patients suspected of acute appendicitis.
Eur J Clin Chem Clin Biochem 1991;29:749-52.

6. Paajanen H, Mansikka A, Laato M, Kettunen J, Kostiainen $\mathrm{S}$. Are serum inflammatory markers age dependent in acute appendicitis? J Am Coll Surg 1997;184:303-8.

7. Hanley JA, McNeil BJ. The meaning and use of the area under a receiver operating characteristic (ROC) curve. Radiology 1982;143:29-36.

8. Greiner M, Pfeiffer D, Smith RD. Principles and practical application of the receiver-operating characteristic analysis for diagnostic tests. Prev Vet Med 2000;45:23-41.

9. Sasso RD, Hanna EA, Moore DL. Leukocytic and neutrophilic counts in acute appendicitis. Am J Surg 1970;120:5636.

10. Bolton JP, Craven ER, Croft RJ, Menzies-Gow N. An assessment of the value of the white cell count in the management of suspected acute appendicitis. Br J Surg 1975;62:906-8.

11. Lau WY, Ho YC, Chu KW, Yeung C. Leucocyte count and neutrophil percentage in appendicectomy for suspected appendicitis. Aust N Z J Surg 1989;59:395-8.

12. van Dieijen-Visser MP, Go PM, Brombacher PJ. The value of laboratory tests in patients suspected of acute appendicitis. Eur J Clin Chem Clin Biochem 1991;29:749-52.

13. Andersson RE, Hugander AP, Ghazi SH, Ravn H, Offenbartl SK, Nyström PO, et al. Diagnostic value of disease history, clinical presentation, and inflammatory parameters of appendicitis. World J Surg 1999;23:133-40.

14. Rodríguez-Sanjuán JC, Martín-Parra JI, Seco I, García-Castrillo L, Naranjo A. C-reactive protein and leukocyte count in the diagnosis of acute appendicitis in children. Dis Colon Rectum 1999;42:1325-9.

15. Körner H, Söreide JA, Söndenaa K. Diagnostic accuracy of inflammatory markers in patients operated on for suspected acute appendicitis: a receiver operating characteristic curve analysis. Eur J Surg 1999;165:679-85. 